Replication

\title{
A dirty store is a cost forever: The harmful influence of disorderly retail settings on unethical consumer behavior
}

\author{
Saar Bossuyt ${ }^{\mathrm{a}, *}$, Patrick Van Kenhove ${ }^{\mathrm{a}}$, Tine De Bock ${ }^{\mathrm{b}}$ \\ a Department of Marketing, Faculty of Economics and Business, Ghent University, Tweekerkenstraat 2, 9000 Ghent, Belgium \\ ${ }^{b}$ Center for Business Management Research, Faculty of Economics and Business, KU Leuven Campus Brussels, Warmoesberg 26, 1000 Brussels, Belgium
}

\section{A R T I C L E I N F O}

\section{Article history:}

First received on June 29, 2015 and was under review for $4 \frac{1}{2}$ months

Available online $\mathrm{xxxx}$

Replication Editor: Eric Bradlow

\section{Keywords:}

Ambient cues

Disorder

Norms

Retail

Unethical consumer behavior

\begin{abstract}
A B S T R A C T
In this paper, we employ insights from the field of environmental psychology to investigate whether consumers are more likely to engage in unethical behavior in disorderly retail settings than in orderly retail settings. In particular, we investigate whether the spreading of disorder (Keizer, Lindenberg, \& Steg, 2008), a theory used to explain norm-violating behavior in urban settings, can also explain norm-violating behavior in retail settings. The results from two behavioral experiments and one online study confirm that consumers shopping in retail settings that deviate from the norm that a store should be clean are more likely to engage in different forms of unethical behavior.
\end{abstract}

(c) 2016 Elsevier B.V. All rights reserved.

\section{Introduction}

The spreading of disorder, or the idea that urban deterioration stems from minor signs of disorder, has inspired both policy makers and researchers over the past decades (Keizer, Lindenberg, \& Steg, 2008; Wilson \& Kelling, 1982; Zimbardo, 1973). In a highly influential paper, Keizer et al. (2008) showed in six studies (see Table 3 in Appendix for an overview) that the spreading of disorder originates from a cross-norm effect: People who observe that others violate(d) a certain norm (e.g. littering) are more likely to violate the same or other norms (e.g. stealing). According to Keizer et al. (2008), the mechanism behind this effect is goaldriven: observing norm-violations weakens the salience of the goal to act appropriately, that stimulates people to do the right thing, and strengthens the salience of hedonic and gain goals, that stimulate people to do what makes them feel good (e.g. by being lazy and not making an effort to do the right thing) or to gain resources (Lindenberg \& Steg, 2007).

The present study explores whether the spreading of disorder effect drives norm-violating behavior in retail settings too. Building on the norm that a store should be clean, organized, and clutter-free (i.e. orderly), we investigate whether consumers are more likely to engage in norm-violating behavior while shopping in a retail setting that violates this cleanliness norm. Based on the cross-norm effect, we expect that consumers who observe that others (such as staff or other consumers) did not respect the norm that a store should be kept clean are more likely to disrespect other norms as well. Such behavior that violates generally accepted norms of conduct in commercial environments is often referred to as unethical consumer behavior (Fullerton \& Punj, 2004; Vitell \& Muncy, 1992). This term covers a wide array of norm-violating behaviors, going from severe (e.g. shoplifting) to less severe (e.g. benefiting from a cashier's mistake) (Fullerton \& Punj, 2004; Vitell \& Muncy, 1992). Our hypothesis is thus

\footnotetext{
* Corresponding author.

E-mail addresses: S.Bossuyt@ugent.be (S. Bossuyt), Patrick.Vankenhove@ugent.be (P. Van Kenhove), Tine.Debock@kuleuven.be (T. De Bock).
} 
formulated as follows: 'Consumers shopping in a disorderly retail setting are more likely to engage in unethical behavior than consumers shopping in an orderly retail setting.'

This paper not only replicates the findings of Keizer et al. (2008), but also extends the work in three important ways. First, by investigating the spreading of disorder in controlled circumstances where the likelihood of being sanctioned is equal in the orderly and the disorderly setting, this paper rules out an alternative explanation for the findings of Keizer et al. (2008). In particular, the cues of disorder in the experiments of Keizer et al. (2008) may have conveyed to people that previous normviolations were left unsanctioned and that they can violate additional norms with impunity (Keizer, Lindenberg, \& Steg, 2013). Second, by investigating the impact of disorder cues in retail settings, we are able to investigate a different set of norm-violating behaviors and, in that way, assess the external validity of the findings of Keizer et al. (2008). Third, by exploring consumers' thoughts and feelings in (dis)orderly retail settings, we gain insight into the mechanism behind the spreading of disorder.

\section{Study 1}

\subsection{Procedure}

The first experiment was set up to replicate the spreading of disorder effect in a retail setting. A sales booth selling bags of sweets was set up in the halls of a Western European university restaurant (see Fig. 1 in Appendix). This location was chosen because it regularly features sales booths. The experiment consisted of an orderly and a disorderly condition. In the orderly condition, the environment surrounding the sales booth was clean and the bags of sweets were orderly arranged. In the disorderly condition, the sales booth was surrounded by clutter and the bags of sweets were randomly scattered across the setting, which clearly deviates from the norm of how a clean sales booth should look like. We ran an online pre-test $\left(N=37 ; 23\right.$ females; $M_{\text {age }}=22.84$, $\left.S D_{\text {age }}=1.94\right)$ to determine whether the disorder manipulation was successful. Participants saw pictures of either the disorderly ( $n=19$ ) or the orderly $(n=18)$ sales booth and indicated to what extent they agreed with the statement "this sales booth gives an orderly impression" on a five point Likert scale, ranging from 1 "strongly disagree" to 5 "strongly agree." The results confirmed that the disorderly sales booth $(M=1.11, S D=.32)$ was rated significantly less orderly than the orderly sales booth $(M=3.00, S D=1.33), t(18.81)=5.90, p<.001$.

The sales booth was manned by two sales clerks, each positioned behind a table. One of them was occupied with the selling process, answering questions and referring customers to the second sales clerk, who was occupied with the cash register. A customer would thus choose a bag with the first sales clerk and then check it out with the second sales clerk. One bag of sweets was priced $€ 1.20$, which was clearly displayed on the sales booth. Nevertheless, the sales clerk would consistently undercharge customers $€ 0.20$ and say out loud "That will be $€ 1$ please." Not reporting a cashier's mistake in your favor is classified as unethical consumer behavior (Fullerton \& Punj, 2004; Vitell \& Muncy, 1992). The other sales clerk kept track whether customers corrected the mistake made in their favor (yes $=1$, no $=0$ ) and wrote down the sales booth's condition ( $1=$ disorderly, $0=$ orderly).

\subsection{Sample}

In total, 291 customers (students and university staff) bought a bag of sweets from our sales booth. Sixty-nine participants were excluded from the analysis because they paid the amount due before the cashier had the opportunity to make a mistake in their favor. In addition, 18 participants were not included in the sample because they frequented the sales booth in group. Engagement in unethical behavior can be influenced by the presence of others (Gino, Ayal, \& Ariely, 2009), and we wanted to avoid this potentially confounding factor. Our final sample consisted of 204 customers ( 79 females), of which 96 bought something from the disorderly sales booth.

\subsection{Results and discussion}

Confirming our hypothesis, results showed that customers shopping in the disorderly retail setting were more likely to engage in unethical behavior than customers shopping in the orderly retail setting: $59.4 \%$ of the customers did not report the cashier's mistake in the disorderly retail setting compared to $43.5 \%$ in the orderly retail setting, $X^{2}(1, N=204)=5.11, p=0.024$, $V=0.16$.

\section{Study 2}

The rationale for the second study was twofold. First, we wanted to show the robustness of the effect by replicating it in a different retail environment and with a different outcome variable. Second, we wanted to rule out the possibility that the findings from Study 1 might have been affected by self-selection bias. In particular, the disorderly sales booth might have been more appealing to nonchalant consumers who are probably less likely to notice a miscalculated bill.

We addressed both objectives by changing the environment from field to lab (to avoid self-selection bias), and by altering the outcome variable to an active form of unethical behavior. We created a lab store that was set up either orderly or disorderly and explored whether the degree of unethical behavior was related to the store's condition (see Fig. 2 in Appendix). We set up 
a pre-test $\left(N=90 ; 54\right.$ females; $\left.M_{\text {age }}=20.52, S D_{\text {age }}=1.00\right)$ in which participants were instructed to walk around in the store and evaluate it on neatness and messiness. The pre-test ran for 2 days: Subjects participating the first day $(n=37)$ frequented the orderly store, subjects participating the second day $(n=57)$ frequented the disorderly store. We made a 'disorder' construct $(\alpha=.91)$ out of three questions on a scale from 1 (not at all) to 10 (very much): "How neat is this store?" (reversed), "How messy is this store?" and "How well is this store managed?" (reversed). The results confirmed that the disorderly store $(M=7.38, S D=1.63)$ was considered significantly more disorderly than the orderly store $(M=2.81, S D=1.45), t(88)=$ $-13.67, p<.001$.

\subsection{Procedure}

Participants entered a room adjacent to the lab store and were told they would participate in a shopping experiment. They were granted a shopping budget of $€ 3.00$ and were told they were free to choose whatever product(s) they liked. They were neither obliged to spend the entire budget, nor to choose products for a total value of $€ 3.00$. We told participants that, in order to support realistic, unbiased product choices, full anonymity was guaranteed. More specifically, we made clear that we were only interested in aggregated data, not in individual purchases. Participants did not have to show whatever product(s) they bought in the store and could take these products home afterwards. The level of anonymity and fear of sanctions was thus equal in both conditions. Most products were worth around $€ 1.00, € 2.00$, or $€ 3.00$. However, it was not possible for participants to buy products for the full shopping budget without cheating. Products worth around $€ 1.00$ were priced at $€ 1.10, € 1.20$, $€ 1.60$, or $€ 1.70$. Products worth around $€ 2.00$ were priced at either $€ 2.10, € 2.40, € 2.50$, or $€ 2.60$. Products worth around $€ 3.00$ were priced at $€ 3.10$ or above. Participants went off to the lab store, selected their product( $s$ ), and returned to the adjacent room to participate in other (unrelated) experiments. During this latter phase, we unobtrusively checked which products had disappeared. Taking products for a value that exceeded the shopping budget was labeled as unethical consumer behavior.

\subsection{Sample}

Participants were 86 undergraduates from a Western European university (33 females) who took part in the experiment in exchange for partial course credit. The experiment ran for 3 days. Half of the participants $(n=43)$ frequented the disorderly store, the other half frequented the orderly store.

\subsection{Results and discussion}

As predicted, participants shopping in the disorderly lab store exceeded their budget more frequently compared to participants shopping in the orderly lab store: $23.3 \%$ of the customers took more products than their budget allowed in the disorderly lab store compared to only $7.0 \%$ in the orderly lab store, $X^{2}(1, N=86)=4.44, p=0.035, V=0.23$. These results provide additional support for our hypothesis that people are more likely to commit unethical behavior in disorderly than in orderly retail settings, and add credibility to the results of Study 1.

\section{Study 3}

Study 1 and Study 2 demonstrated the spreading of disorder in retail settings. Study 3 was set up to explore whether this spreading of disorder originates from a cross-norm effect.

Table 1

Reactions to the question "Describe what you see".

\begin{tabular}{|c|c|c|c|}
\hline Reaction to "Describe what you see" contains: & Orderly store & Disorderly store & Proportion test \\
\hline Detailed product descriptions (which products, which brands, healthy or unhealthy products...) & $51 \%$ & $37 \%$ & $\begin{array}{l}z=2.150 \\
p=.032\end{array}$ \\
\hline Global product descriptions (e.g. “products”, “food”, “variety”...) & $30 \%$ & $18 \%$ & $\begin{array}{l}\mathrm{Z}=2.131 \\
\mathrm{p}=.033\end{array}$ \\
\hline Words expressing order (e.g. "structure”, “neat”...) & $9 \%$ & $0 \%$ & $\begin{array}{l}z=3.336 \\
p=.001\end{array}$ \\
\hline Words expressing disorder (e.g. “chaos”, “clutter”, “no overview”, “no structure”...) & $5 \%$ & $38 \%$ & $\begin{array}{l}Z=5.842 \\
p<.001\end{array}$ \\
\hline A store for students & $5 \%$ & $8 \%$ & $\begin{array}{l}Z=.985 \\
p=.325\end{array}$ \\
\hline
\end{tabular}




\subsection{Sample and procedure}

One hundred and fifty-two participants (106 females, $\left.M_{\text {age }}=33.40, S D_{\text {age }}=15.49\right)$ took part in an online study. They were randomly assigned to the disorderly condition $(n=76)$, which featured pictures of a disorderly store, or the orderly condition $(n=76)$, which featured pictures of an orderly store. Participants were asked to describe what they saw on the pictures, and were presented with a scenario about a customer passively benefiting from a cashier's mistake in his favor. Participants had to explain why they believed the customer in the scenario did not respond to the cashier.

\subsection{Results and discussion}

For the cross-norm effect to apply, the retail setting must contain signs of norm-violations and customers must recognize these violations. The results of this study confirm that these two conditions were met. First, the answers to the "Describe what you see"-question confirmed that customers observed a norm-violation. When customers enter a store, they should be solely focused on the products. However, as can be seen in Table 1 below, participants in the disorderly condition were significantly less focused on the products than participants in the orderly condition, and reported significantly more reactions containing disorder-related words.

Second, the answers to the scenario illustrate the presence of a cross-norm effect. As can be seen in Table 2 below, participants in the disorderly condition expressed that the store signals that others did not make an effort to keep the store clean, causing the customer to feel like he should not make an effort to report the cashier's mistake. In addition, the items that indicate a moral justification for having taken too much change (e.g. "it is not such a huge loss for the store", "the customer does not have a relationship with the store") occur virtually only in the orderly condition. Participants in the disorderly condition feel thus less obliged to justify the immoral behavior than participants in the orderly condition. These results show that the normative goal frame is weaker in the disorderly condition, which provides tentative evidence for the goal-framing mechanism proposed by Keizer et al. (2008).

\section{Conclusion}

This research explored whether the spreading of disorder effect (Keizer et al., 2008) holds in retail settings and whether it serves as a driver of unethical consumer behavior. Three studies confirmed the robustness of the effect and demonstrated that consumers shopping in disorderly retail settings are more likely to engage in unethical behavior than consumers shopping in orderly retail settings.

These findings have important implications for various streams of research. First, this research contributes to the field of environmental psychology by ruling out an alternative explanation for the results of Keizer et al. (2008). By demonstrating the

Table 2

Reactions to the question "Why do you think the customer in the scenario does not react?"

\begin{tabular}{|c|c|c|c|}
\hline Reactions to the passively benefiting scenario & $\begin{array}{l}\text { Orderly } \\
\text { store }\end{array}$ & $\begin{array}{l}\text { Disorderly } \\
\text { store }\end{array}$ & $\begin{array}{l}\text { Proportion } \\
\text { test }\end{array}$ \\
\hline $\begin{array}{l}\text { Opportunism (e.g. "the customer is not going to say no to some extra cash", "the customer is happy with the extra } \\
\text { money"...) }\end{array}$ & $39 \%$ & $34 \%$ & $\begin{array}{l}\mathrm{Z}=.991 \\
\mathrm{p}=.322\end{array}$ \\
\hline $\begin{array}{l}\text { Neutralization - Cashier's fault (e.g. "the cashier should pay attention”, "it's not the customer's fault that the cashier } \\
\text { makes a mistake"...) }\end{array}$ & $17 \%$ & $12 \%$ & $\begin{array}{l}\mathrm{Z}=1.200 \\
\mathrm{p}=.230\end{array}$ \\
\hline $\begin{array}{l}\text { Neutralization - No huge loss for the store (e.g. "the store's price level is high, they won't notice it", "the products are } \\
\text { already expensive, the store won't miss it"...) }\end{array}$ & $11 \%$ & $2 \%$ & $\begin{array}{l}\mathrm{Z}=3.521 \\
\mathrm{p}<.001\end{array}$ \\
\hline $\begin{array}{l}\text { The customer did not notice the mistake (e.g. "the customer was not paying attention", "the customer does not know } \\
\text { the price"...) }\end{array}$ & $11 \%$ & $6 \%$ & $\begin{array}{l}\mathrm{Z}=1.743 \\
\mathrm{p}=.081\end{array}$ \\
\hline $\begin{array}{l}\text { No relation with the store (e.g. "the person is no loyal customer", "the customer does not have a relationship with the } \\
\text { store"...) }\end{array}$ & $11 \%$ & $2 \%$ & $\begin{array}{l}\mathrm{Z}=3.381 \\
\mathrm{p}=.001\end{array}$ \\
\hline Dissatisfaction (e.g. "the store is disorderly so the customer feels he should be repaid for his”...) & $6 \%$ & $18 \%$ & $\begin{array}{l}Z=3.541 \\
p<.001\end{array}$ \\
\hline Price not clear (e.g. "the price on the shelf was probably not clear", "maybe the shelf still featured an old price”...) & $3 \%$ & $3 \%$ & $\begin{array}{l}Z=0.000 \\
p=1\end{array}$ \\
\hline No time (e.g. "the customer is in a hurry", "the customer does not want to waste time"...) & $2 \%$ & $3 \%$ & $\begin{array}{l}\mathrm{Z}=1.013 \\
\mathrm{p}=.311\end{array}$ \\
\hline Shyness (e.g. "maybe the customer does not dare to correct the cashier", "the customer is shy”...) & $1 \%$ & $2 \%$ & $\begin{array}{l}\mathrm{Z}=1.006 \\
\mathrm{p}=.315\end{array}$ \\
\hline Customer should respond (e.g. "the customer should have responded, the staff of this store is worth his response") & $1 \%$ & $0 \%$ & $\begin{array}{l}\mathrm{Z}=1.418 \\
\mathrm{p}=.156\end{array}$ \\
\hline $\begin{array}{l}\text { Goal-framing mechanism (e.g. "the customer observes nonchalance and will behave nonchalant too", "the store owner } \\
\text { does not seem to care, and so does the customer"...) }\end{array}$ & $0 \%$ & $18 \%$ & $\begin{array}{l}\mathrm{Z}=6.029 \\
\mathrm{p}<.001\end{array}$ \\
\hline
\end{tabular}


spreading of disorder effect in controlled circumstances where the likelihood of being sanctioned is equal in the orderly and the disorderly setting, this paper rules out the theory that disorder spreads from one norm-violation to another because cues of disorder signal that previous norm-violations were left unsanctioned (Keizer et al., 2013). Our results seem thus to be consistent with the goal-driven mechanism suggested by Keizer et al. (2008). However, further research is required to investigate another alternative explanation, namely that customers commit unethical behavior to punish the staff for violating the norm that a store should be kept clean.

Second, by investigating the impact of a negative ambient cue (disorder) on negative behavior (unethical behavior), the research provides new insights to the retailing literature. Previous research in this area mainly focused on the effects of positive ambient cues (e.g. nice scents) on positive behavior (e.g. increased spending) (Turley \& Milliman, 2000). This study addressed these two gaps.

Third, the present findings contribute to the field of consumer ethics by improving our understanding of the possible causes of unethical consumer behavior. Knowing the circumstances under which consumers are more likely to commit unethical behavior is important, as many of these acts are not planned in advance (Fullerton \& Punj, 2004). This latter contribution is relevant for practitioners too, given the high cost of unethical consumer behavior for retailers. For instance, the annual cost of shoplifting in the UK has been estimated at about 35 million BPS or over 50 million USD (BRC, 2015).

\section{Appendix A}

Table 3

Comparison Keizer et al. (2008) and Present research (2015).

\begin{tabular}{|c|c|c|c|c|c|c|}
\hline \multirow[t]{13}{*}{ Keizer et al. (2008) } & \multirow[t]{2}{*}{ Study } & \multirow[t]{2}{*}{ Environment } & \multirow[t]{2}{*}{ Conditions } & \multirow[t]{2}{*}{ DV } & \multicolumn{2}{|l|}{ Results } \\
\hline & & & & & Order & Disorder \\
\hline & 1 & Bicycle parking in shopping area & $\begin{array}{l}\text { Order }(\mathrm{N}=77)-\text { Clean walls } \\
\text { Disorder }(\mathrm{N}=77)-\text { Walls covered with } \\
\text { graffiti }\end{array}$ & Littering & \multicolumn{2}{|c|}{$\begin{array}{l}X^{2}(1,154)=20.37 \\
p<.001\end{array}$} \\
\hline & Study & Environment & Conditions & DV & \multirow{2}{*}{\multicolumn{2}{|c|}{$\begin{array}{ll}\text { Results } & \\
\text { Order } & \text { Disorder } \\
27 \% & 82 \% \\
\text { trespassed } & \text { trespassed } \\
X^{2}(1,93)= & 27.91 \\
p<.001 & \end{array}$}} \\
\hline & 2 & $\begin{array}{l}\text { Parking lot with temporary } \\
\text { fence closing off the main } \\
\text { entrance }\end{array}$ & $\begin{array}{l}\text { Order }(\mathrm{N}=44)-\text { No bicycles locked to } \\
\text { the fence } \\
\text { Disorder }(\mathrm{N}=49)-\text { Bicycles locked to } \\
\text { the fence ( }=\text { forbidden by a sign })\end{array}$ & Trespassing & & \\
\hline & Study & Environment & Conditions & DV & \multirow{2}{*}{\multicolumn{2}{|c|}{$\begin{array}{ll}\text { Results } & \\
\text { Order } & \text { Disorder } \\
30 \% & 58 \% \\
\text { littered } & \text { littered } \\
X^{2}(1,120)=9.77 \\
p=.002 & \end{array}$}} \\
\hline & 3 & $\begin{array}{l}\text { Parking garage adjacent to a } \\
\text { supermarket and health club }\end{array}$ & $\begin{array}{l}\text { Order }(\mathrm{N}=60)-\text { No shopping carts left } \\
\text { unreturned } \\
\text { Disorder }(\mathrm{N}=60) \text { - Four unreturned } \\
\text { shopping carts standing around in } \\
\text { disarray }\end{array}$ & Littering & & \\
\hline & Study & Environment & Conditions & DV & \multirow{2}{*}{\multicolumn{2}{|c|}{$\begin{array}{ll}\text { Results } & \\
\text { Order } & \text { Disorder } \\
52 \% & 80 \% \\
\text { littered } & \text { littered } \\
X^{2}(1,96)= & 8.59 \\
p=.003 & \end{array}$}} \\
\hline & 4 & Bicycle shed near train station & $\begin{array}{l}\text { Order }(\mathrm{N}=50)-\text { No sound of (prohibited) } \\
\text { fireworks } \\
\text { Disorder }(\mathrm{N}=46) \text { - Sound of } \\
\text { (prohibited) fireworks }\end{array}$ & Littering & & \\
\hline & Study & Environment & $\begin{array}{l}\text { Conditions } \\
\text { Order }(\mathrm{N}=71)-\text { Mailbox not covered in }\end{array}$ & DV & $\begin{array}{l}\text { Results } \\
\text { Order }\end{array}$ & Disorder \\
\hline & 5 & $\begin{array}{l}\text { Envelope visibly containing } € 5 \\
\text { hanging out of a mailbox }\end{array}$ & $\begin{array}{l}\text { graffiti } \\
\text { Disorder }(\mathrm{N}=60)-\text { Mailbox covered in } \\
\text { graffiti }\end{array}$ & Stealing the $€ 5$ & $\begin{array}{l}13 \% \text { stole } \\
X^{2}(1,131) \\
p=.035\end{array}$ & $\begin{array}{l}27 \% \text { stole } \\
=4.12\end{array}$ \\
\hline & Study & Environment & $\begin{array}{l}\text { Conditions } \\
\text { Order }(N=71)-\text { Mailbox without litter on }\end{array}$ & DV & $\begin{array}{l}\text { Results } \\
\text { Order }\end{array}$ & Disorder \\
\hline & 6 & $\begin{array}{l}\text { Envelope visibly containing } € 5 \\
\text { hanging out of a mailbox }\end{array}$ & $\begin{array}{l}\text { the ground } \\
\text { Disorder }(\mathrm{N}=72)-\text { Mailbox with litter } \\
\text { on the ground }\end{array}$ & Stealing the $€ 5$ & \multicolumn{2}{|c|}{$\begin{array}{l}X^{2}(1,143)=3.55 \\
p=.047\end{array}$} \\
\hline \multirow[t]{4}{*}{$\begin{array}{l}\text { Present research } \\
\text { (2015) }\end{array}$} & Study & Environment & Conditions & DV & $\begin{array}{l}\text { Results } \\
\text { Order }\end{array}$ & Disorder \\
\hline & 1 & $\begin{array}{l}\text { Sales booth in university } \\
\text { building }\end{array}$ & $\begin{array}{l}\text { Order }(\mathrm{N}=108)-\text { Sales booth set up orderly } \\
\text { Disorder }(\mathrm{N}=96) \text { - Sales booth set up } \\
\text { disorderly }\end{array}$ & $\begin{array}{l}\text { Benefit from } \\
\text { cashier's mistake }\end{array}$ & \multicolumn{2}{|c|}{$\begin{array}{l}X^{2}(1,204)=5.11 \\
p=.024\end{array}$} \\
\hline & Study & Environment & Conditions & DV & $\begin{array}{l}\text { Results } \\
\text { Order }\end{array}$ & Disorder \\
\hline & 2 & Lab store & $\begin{array}{l}\text { Order }(\mathrm{N}=43) \text { - Lab store set up orderly } \\
\text { Disorder }(\mathrm{N}=43) \text { - Lab store set up } \\
\text { disorderly }\end{array}$ & $\begin{array}{l}\text { Taking more } \\
\text { products than } \\
\text { budget allows }\end{array}$ & $\begin{array}{l}X^{2}(1,86)=4.44 \\
p=.035\end{array}$ & $\begin{array}{l}23 \% \text { took } \\
\text { more } \\
=4.44\end{array}$ \\
\hline
\end{tabular}




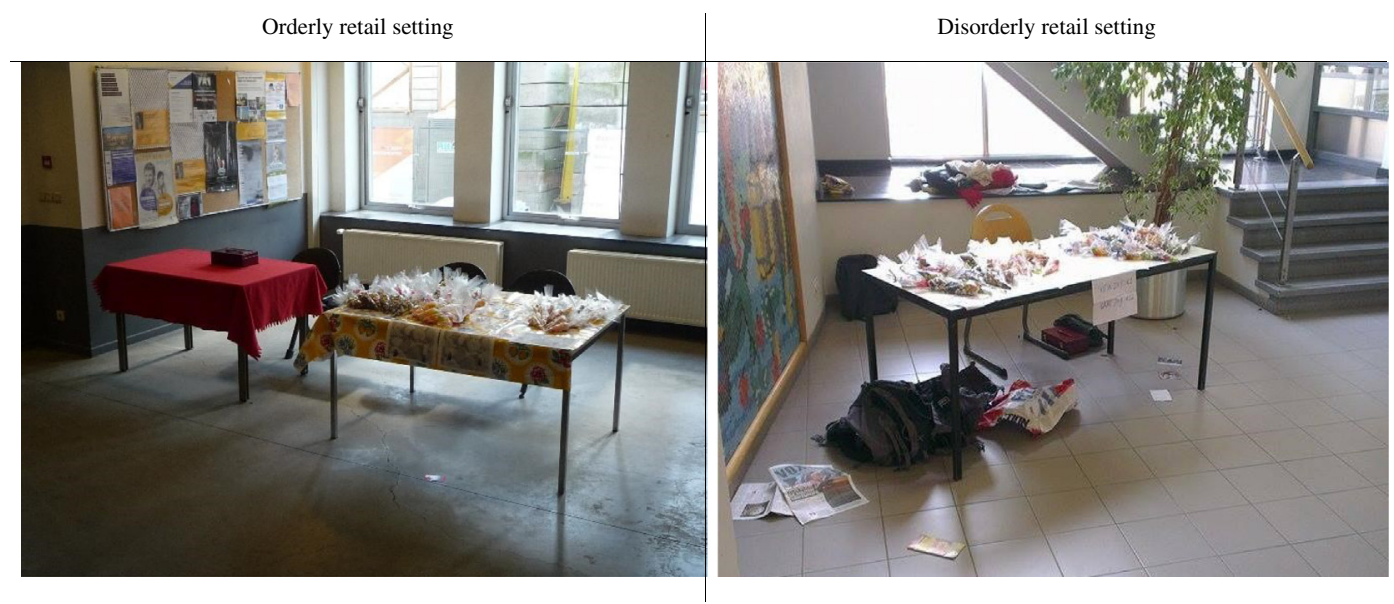

Fig. 1. Pictures Study 1.

Orderly retail setting
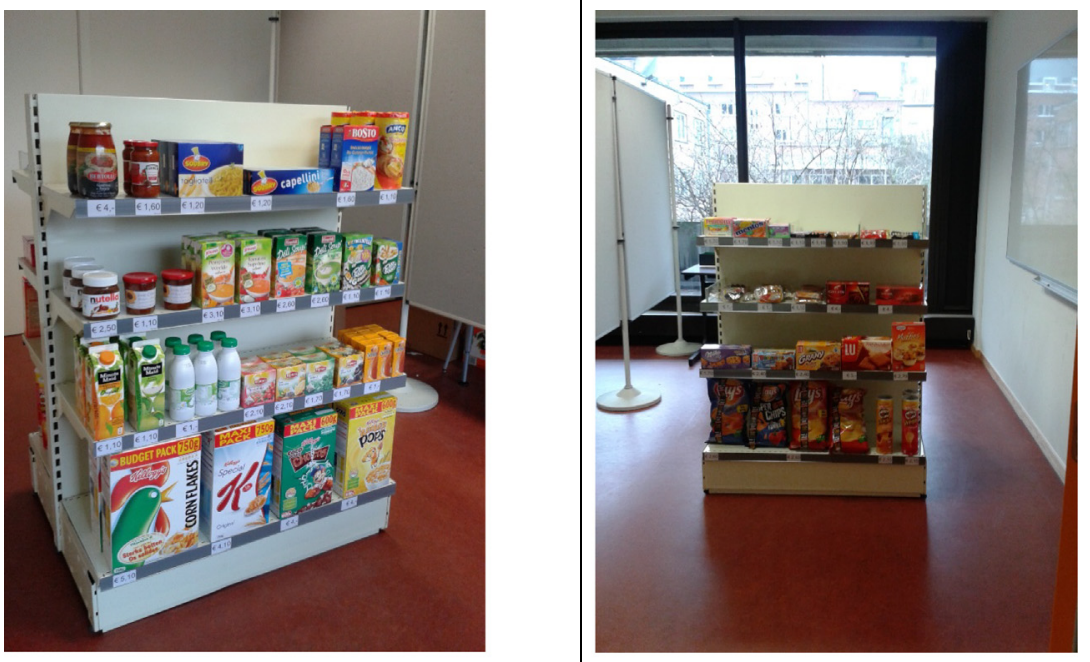

Disorderly retail setting
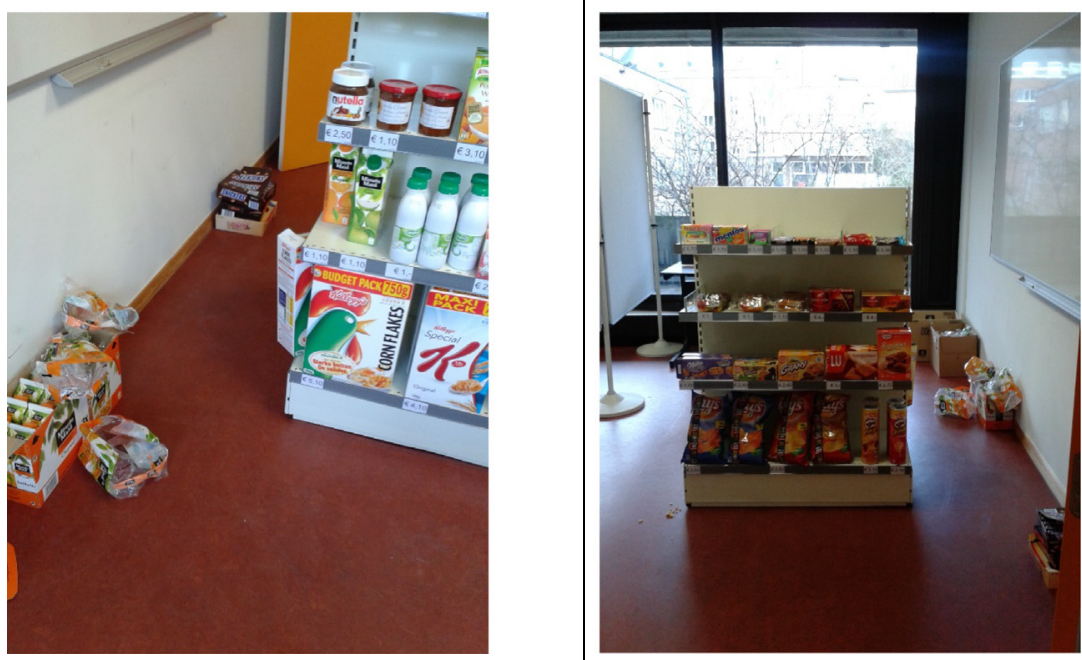

Fig. 2. Pictures Study 2. 


\section{References}

BRC (2015). BRC retail crime survey, 2014.

Fullerton, R. A., \& Punj, G. (2004). Repercussions of promoting an ideology of consumption: Consumer misbehavior. Journal of Business Research, 57(11), 1239-1249. http://dx.doi.org/10.1016/s0148-2963(02)00455-1.

Gino, F., Ayal, S., \& Ariely, D. (2009). Contagion and differentiation in unethical behavior the effect of one bad apple on the barrel. Psychological Science, 20(3), 393-398. Keizer, K., Lindenberg, S., \& Steg, L. (2008). The spreading of disorder. Science, 322(5908), 1681-1685.

Keizer, K., Lindenberg, S., \& Steg, L. (2013). The importance of demonstratively restoring order. PloS One, 8(6), e65137.

Lindenberg, S., \& Steg, L. (2007). Normative, gain and hedonic goal frames guiding environmental behavior. Journal of Social Issues, 63(1), 117-137.

Turley, L. W., \& Milliman, R. E. (2000). Atmospheric effects on shopping behavior: A review of the experimental evidence. Journal of Business Research, 49(2), $193-211$. Vitell, S. J., \& Muncy, J. (1992). Consumer ethics: An empirical investigation of factors influencing ethical judgments of the final consumer. Journal of Business Ethics, 11(8), 585-597. http://dx.doi.org/10.1007/BF00872270.

Wilson, J. Q., \& Kelling, G. L. (1982). Broken windows. Atlantic Monthly, 249(3), 29-38.

Zimbardo, P. G. (1973). A field experiment in auto shaping. Vandalism (pp. 85-90). 